Public Abstract

First Name:Claude

Middle Name:Randal

Last Name:Westfall

Adviser's First Name:Wendy

Adviser's Last Name:Sims

Co-Adviser's First Name:

Co-Adviser's Last Name:

Graduation Term:FS 2008

Department:Music

Degree:PhD

\title{
Title:CRITERIA IDENTIFIED BY SELECTED MISSOURI HIGH SCHOOL CHORAL DIRECTORS FOR PLACEMENT OF CONCERT REPERTOIRE IN CONCERT ORDER
}

This descriptive study was designed to investigate the criteria used by selected Missouri high school choral music educators for sequencing repertoire on concert programs. The purposes were to (a) examine choral music educatorsâ€ $€^{\mathrm{TM}}$ rationales for placing each piece in order on a concert program, (b) identify criteria used by choral music educators when selecting the first and last song to place on a concert program, and (c) determine whether experienced successful choral music educators employ common strategies when creating a concert program, which might be useful for consideration by other choral music educators. Participants were Missouri high school choral music teachers $(\mathrm{N}=22)$ who had been recommended by a panel of university choral directors, based on the teachersâ€ ${ }^{\mathrm{TM}}$ experience and success in the choral classroom. Participants were asked to consider the latest non-holiday concert presented by their top ensemble and respond to a questionnaire about how they determined the concert order for each piece of literature performed. For each repertoire selection, they were instructed to provide their reasons for placing the piece in itâ€ $\epsilon^{\mathrm{TM}} \mathrm{S}$ spot on the program and to explain how influential these reasons were in their decision making process. A list of possible categories to address was provided for their reference, including aesthetic elements, musical fit, teaching goals, quality of music, historical/multicultural considerations, and extra musical influences.

Results revealed that the surveyed directors based program order decisions on a wide diversity of rationale. Several were found to be common among the respondents however, including (a) appeal to particular individuals or groups, (b) variety through the use of contrast and unity among the pieces, and (c) teaching goals related to intended student learning outcomes from the concert experience. 